原著

\title{
部分的末梢前庭障害モデルの前庭機能評価法
}

\author{
下郡＼cjkstart博明・堀池＼cjkstart修・池田＼cjkstart卓生・山下 裕司
}

\section{Evaluation of Vestibular Function in Animal Models with Partial Peripheral Vestibular Disorder}

\author{
Hiroaki Shimogori, Osamu Horiike, Takuo Ikeda, Hiroshi Yamashita \\ Department of Otolaryngology, Yamaguchi University School of Medicine
}

In this study we used the trapezoid rotation test to evaluate vestibular function in normal guinea pigs or guinea pigs with peripheral vestibular disorder. Post-rotatory nystagmus (PRN) was recorded on videotape under dark conditions with an infrared charge-coupled device camera. The analysis was performed using the pubic domain NIH Image program, and the horizontal and vertical components were calculated automatically. The mean value of maximum slow phase velocity (MSPV) in the normal guinea pigs and guinea pigs with vestibular disorder was $37.288 \pm 9.423 \mathrm{degree} / \mathrm{sec}$ and $9.786 \pm 2.758 \mathrm{degree} / \mathrm{sec}$ respectively. There was a significant correlation between the PRN number and MSPV.

We consider that this system makes it possible to evaluate vestibular function in animal models easily and inexpensively.

Key words: trapezoid rotation, post-rotatory nystagmus, maximum slow phase velocity, guinea pig

はじめに

種々の動物モデルに対して，聴覚機能の評価法 は確立されているが，前庭機能に関してはその評 価法は遅れている。また，動物モデルの前庭機能 を評価した報告は, サーチコイルや発光ダイオー ドを用いたものもあるが，動物への侵襲が大きな ものであった12)。我々はこれまでヒトの眼球運 動を, パソコンと赤外線 CCD カメラを用いて解 析する簡易システムを開発し，報告した 度はこの方法を応用して, 非侵襲的にモルモット の眼球運動を解析する方法を開発した。そして正

山口大学医学部耳鼻咽喉科学教室 新専門会員
常モルモット，一側末梢前庭障害を作製したモル モットに回転刺激を与兄, 出現した回転後眼振の 最大緩徐相速度を測定することができたので報告 する。

方法

対象は, プライエル反射正常, 両鼓膜正常の ートレイ系白色モルモットで, 無処置14匹（正 常群), 右外側半規管切断後 3 日目の 7 匹 (障害 群）である。

外側半規管切断は, 我々が過去に報告した方法 に準じて行っだ)。ネンブタールツ $(27 \mathrm{mg} / \mathrm{kg})$ 腹腔内麻䣷下に耳後部の皮下に $1 \%$ キシ口カイ ン® $1.5 \mathrm{ml}$ を注射し, 耳後部を切開し, 乳突骨 胞を開放した。手術用顕微鏡下にバーで外側半規 

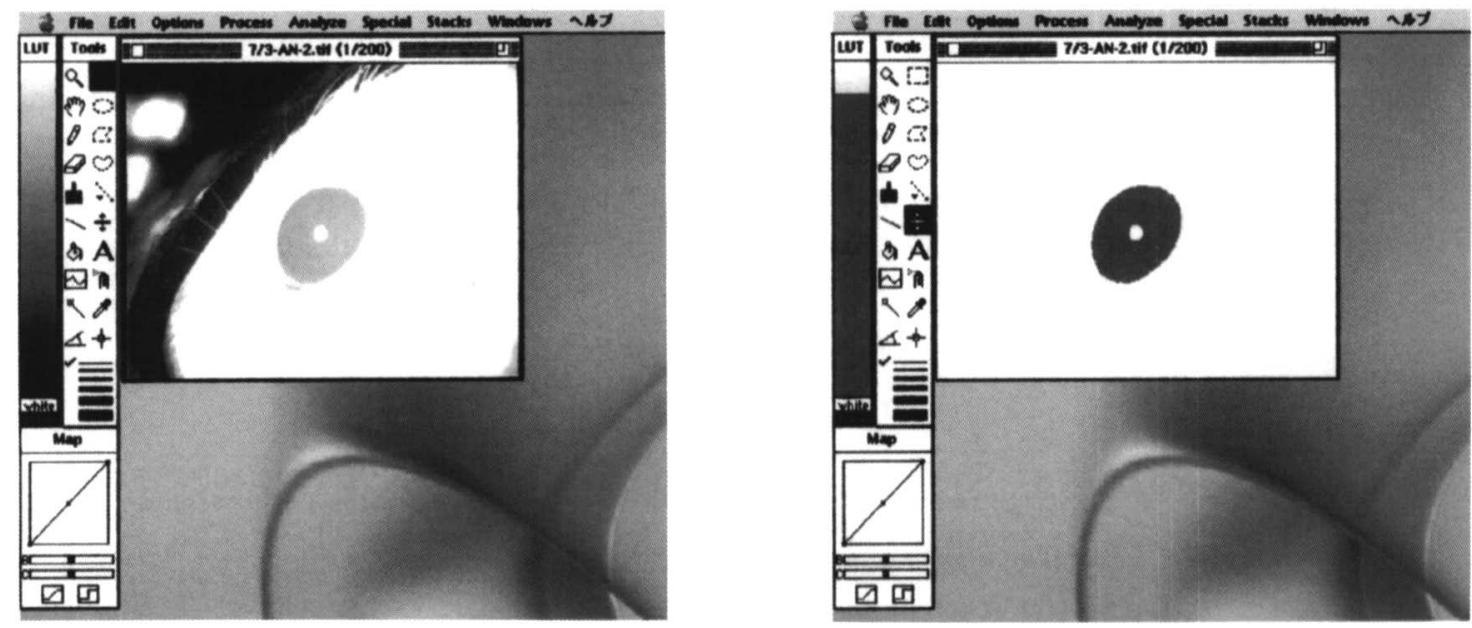

図 1 瞳孔の閾値の設定

眼球運動をパソコンに取り込んだ後 (左図), 関心領域を決定して, 瞳孔の閾値を設定して認識させる（右 図)。

管を切断した。リンパ液を単脚側から 2 秒間吸引 後, 同部をボルヒール® [藤沢薬品工業 (株)］ で閉鎖した。感染予防のため術野にペントシリ ン®粉末を少量散布した後, 創部を縫合して同薬 剂を $50 \mathrm{mg} / \mathrm{kg}$ 筋注した。縫合部は消毒後テラマ イシン®軟膏を塗布した。

回転検査には，第一医科株式会社製回転装置を 用いた。回転刺激は, 過去に我々が報告した方法 と同様である5)。すなわち, 角加速度 $10 \mathrm{deg} / \mathrm{sec}^{2}$ で回転を開始して, 定速 $180 \mathrm{deg} / \mathrm{sec}$ になった後 $60 \mathrm{sec}$ 回転させ, 角減速度 $75 \mathrm{deg} / \mathrm{sec}^{2}$ で停止さ せた。暗所開眼下で回転後眼振をビデオテープに 録画した。得られたデータを, 当教室の池田が報 告したヒト用の簡易眼球運動解析法を応用して解 析した3)。フリーウェアーの画像解析ソフトであ る NIH Image を用いて，まずモルモットの瞳孔 を認識するため, 瞳孔の輪郭が明瞭㑤き出され るように，閾値を設定した（図1)。これにより， モルモットの後眼振を ENG と同様の波形データ としてとらえることがでさた（図 2 )。モルモッ 卜の摘出眼球 10 個の眼球径と瞳孔径を測定して平 均值を求め, この值を用いてモルモットの瞳孔の 中心座標から, 水平方向と垂直方向の眼球運動を 計算し, 緩徐相速度を算出した。

正常群と障害群で, 最大緩徐相速度に統計学的 に有意差があるかを Mann-WhitneyのU 検定を

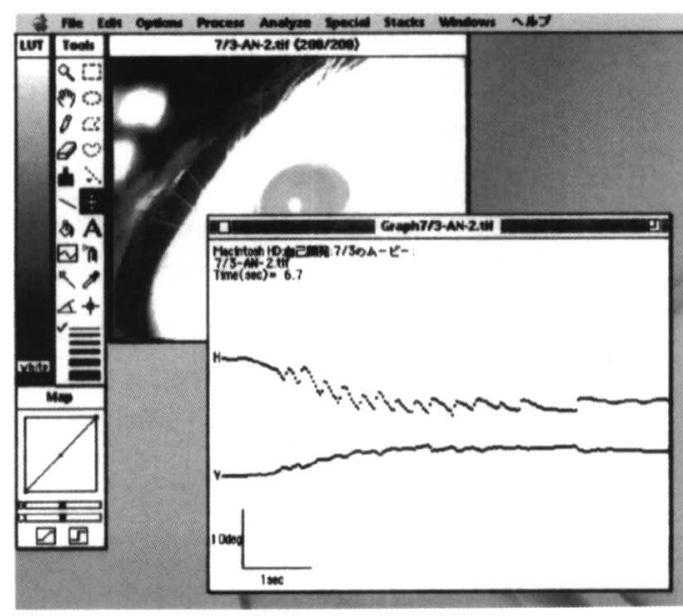

図 2 解析波形

波形グラフは, 上段が水平方向, 下段が垂 直方向を示す。ENG と同等の波形が得ら れる。

用いて調べた。また, 回転後眼振数と, 最大緩徐 相速度の間に相関が認められるかどらかについて 調べた。

結果

無処置群では, 時計方向回転, 反時計方向回転 をあわせた28個のデータのうち, 体動で解析困難 の 2 個を除き, $\mathrm{n}=26$ として解析した。最大緩徐 相速度の平均値は, $37.288 \pm 9.423 \mathrm{deg} / \mathrm{sec}(\mathrm{M} \pm$ 


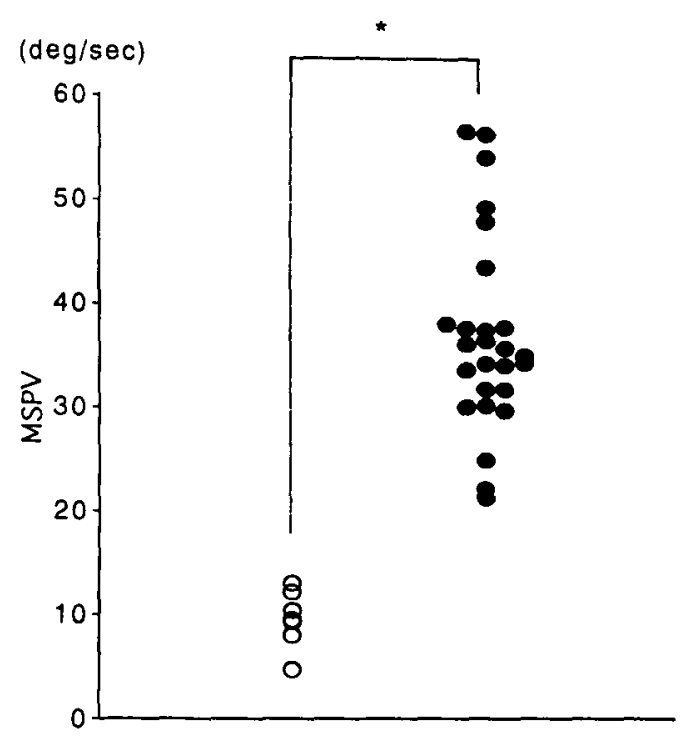

㜔害群正常群

図 3 障害群, 正常群の最大緩徐相速度 障害群の MSPV(maximum slow phase velocity) は正常群と比較して，有意に小 さい值を示している $\left.{ }^{*} \mathrm{p}<0.0001\right) 。$

SD）であった。障害群では，障害側の外側半規 管機能を主として反映する, 反時計回転の後眼振
のデータを用い， $\mathrm{n}=7$ として解析した。最大緩 徐相速度の平均値は， $9.786 \pm 2.758 \mathrm{deg} / \mathrm{sec}(\mathrm{M} \pm$ SD）であった（図 3）。最大緩徐相速度に関して は, Mann-Whitney のU検定では $\mathrm{p}<0.0001 て ゙$ 2 群間で有意差を認めた。

無処置群の26例，障害群の 7 例をあわせた33例 について，各々の回転後眼振数に対する最大緩徐 相速度の值をプロットした。その結果，回転後眼 振数と最大緩徐相速度との間には, 統計学上有意 な相関が認められた $(r=0.592, n=33, p=0.0002)$ (図 4 )。

\section{考察}

我々は，種々の薬剂の内耳に対する影響を調 べ，臨床的に内耳へ直接的に投与可能な薬剤を検 討寸ることを目的に，浸透王ポンプを用いた実験 を続けてきた4) 7)。浸透圧ポンブを用いた実験の 大きな問題点は，ポンプのカニューレ脱落と感染 でする。そしてこれらの問題点を生じることな く，非侵襲的に前庭機能が評価できるシステムを 確立してきた5)。その間我々は一貫して，前庭機 能評価の指標のひとつとして回転後眼振数を用い てきた。これを指標にして，ステロイドホルモン が正常時には末梢前庭機能を安定させ，障害時に は興偣性に作用する可能性を突さ止めた4)6)。乙

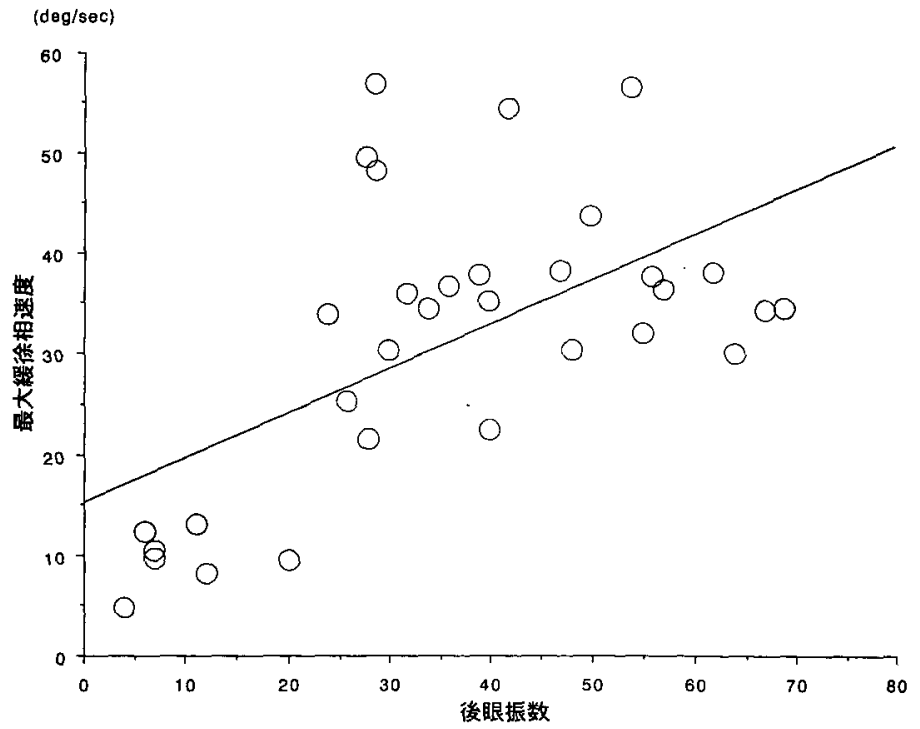

図 4 回転後眼振数之最大緩徐相速度との相関

回転後眼振数と最大緩徐相速度との間には, 統計学上有意な相関が認められる $(r=0.592, n=33, p=$ 0.0002)。 
かし，過去の臨床研究，基礎研究では，主に温度 眼振の持続時間やVOR gain の測定が前庭機能 評価に用いられており，動物モデルに物いて後眼 振数がどれ注ど前庭機能を反映するのかについて は解決しなければならない問題であった。本研究 では, 後眼振数と最大緩徐相速度との間には有意 な相関を認めたことから，後眼振数を用いた前庭 機能評価法は信頼性があったと考える。

本システムの問題点として, 体動の影響を全く なくすことができず，データが使えない場合がわ ずかながらあったことである。過度の固定は，動 物に負担をかけることになり，また压迫のため閉 眼してしまらこともある。データがらまく取れ ず，繰り返して検查をしても response decline が生じてしまう。我々のこれまでの実験から，モ ルモットに 3 分間のインターバルを拈いて連続し て回転刺激它加克ると，1，2回目に比べて 3 回 目以降は後眼振数が減少してくる傾向があること がわかっている。この問題を解決寸るためには, より生理的な刺激で, response decline が生じに くい振子様回転刺激を用いた方が望ましい。臨床 データとしてはVOR gain が数多く報告されて いることからす，本システムで得られた実験モデ ルのデータを臨休データと比較するためにも, 今 後は振子用回転刺激を行い, 最大緩徐相速度を求 めることで VOR gain を計測することがよいと 考㝋た。

\section{まとめ}

1. 赤外線 CCD カメラとパソコンを用いた眼 球運動画像解析法を用いて，モルモットの回転後 眼振を解析した。

2. 本システムを用いて, 安定的に最大緩徐相 速度の測定が可能であることがわかった。

3 . 回転後眼振数と最大緩徐相速度との間に は，有意な相関を認めた。
本論文の要旨の一部は, 第59回日本めまい平衡 医学会総会（東京）で発表した。な特，本研究の 一部は平成12-13年度文部省科学研究費（基盤研 究 C No 12671669）の補助にて行われた。

文献

1) Pettorossi VE, Bamonte F, Ericco P, et al: Vestibulo-ocular reflex (VOR) in guinea pigs. Acta Otolaryngol (Stockh) 101: 378388, 1986

2) Escudero $M$, de Waele $C$, Vibert $N$, et al: Saccadic eye movements and the horizontal vestibulo-ocular and vestibulo-collic reflexes in the intact guinea-pig. Exp Brain Res 97: 254-262, 1993

3）池田卓生, 綿貫浩一, 菅原一真, 他: 赤外線 CCD カメラとパソコンを用いた簡易的眼球 運動画像解析法. Equilibrium Res 59: 298305,2000

4) Shimogori H, Yamashita H: Efficacy of intracochlear administration of betamethasone on peripheral vestibular disorder in the guinea pig. Neurosci Lett 294: 21-24, 2000

5 ）下郡博明, 菅原一真, 池田卓生, 他 : 浸透圧 ポンプ留置モデルの前庭機能評価法. Equilibrium Res 59: 306-310, 2000

6 ) Shimogori H, Yamashita H, Watanabe T, et al: A role of glucocorticoid receptors in the guinea pig vestibular system. Brain Res 851 : 258-260, 1999

7) 下郡博明, 山下裕司, 高橋正紘: 浸透圧ポン プKよる内耳への直接的薬剤注入法の検討.

Otol Jpn 7: 109-113, 1997

$\left(\begin{array}{l}\text { 原稿到着 : 平成13年 } 3 \text { 月 } 12 \text { 日 } \\ \text { 別刷請求先 : 下郡博明 } \\ \text { 干755-8505 山口県宇部市南小串1-1-1 } \\ \text { 山口大学医学部耳鼻咽喉科学教室 }\end{array}\right)$

